\title{
William Arnold and Experimental Education in North India, 1855-1859: An Innovative Model of State Schooling
}

\author{
Tim Allender
}

This article is about a progressive experiment concerning state-sponsored schooling that was carried out in north India in the early 1850 s. It was on a large scale and, almost uniquely, aimed to engage the poor village boy by building a system designed to wean him onto a sympathetic curriculum that contained both Western and Eastern elements. Even though it was to eventually fail, William Arnold, who implemented the Indian experiment, aimed to avoid the pitfalls of the class-based, English education system by offering village boys the prospect of promotion across a unitary government curriculum that could eventually result in a college education. In this way he hoped to overcome the barriers of both race and class. Arnold's government-run scheme predated William Forster's Education Act of 1870 in England even though the precursors for the Indian experiment related to "orientalist" thought that had emerged on the subcontinent a generation earlier.

Cet article traite d'une expérience progressiste touchant l'enseignement public, qui fut menée dans le nord de l'Inde au début des années 1850. C'était une expérience de grande envergure qui visait presque uniquement les garçons des villages pauvres pour lesquels on élabora un système destiné à les orienter vers un programme comprenant des éléments venant à la fois de l'Ouest et de l'Est. Même si cette tentative était en définitive vouée à l'échec, William Arnold, le responsable de cette expérience, cherchait à éviter les pièges d'un système d'éducation anglais basé sur la classe sociale, en offrant aux jeunes garçons des villages une perspective d'avancement dans un programme d'études gouvernemental unitaire qui pouvait éventuellement mener à des études collégiales. Il espérait ainsi surmonter les barrières de race et de langue. Le projet gouvernemental d'Arnold précéda la loi de l'instruction publique de William Forster adoptée en Angleterre en 1870 bien que la pensée « orientaliste » des précurseurs de l'expérience indienne soit apparue sur le sous-continent indien une génération plus tôt.

Historians of education have paid considerable attention in the past to the Forster Education Act of 1870, which marked the foundation of English and Welsh state education systems. German and French ideas were the most significant philosophical influence on it and contemporary educationalists like Matthew Arnold often made that point, even when writing to interested friends in India. However, progressive experiments were also launched in individual colonies well before 1870. Innovative administrators there could use their power to attempt bold initiatives that could not have been so easily tried in England, given the complex political landscape that needed to be 
navigated. But such possibilities were evident, especially in the so-called "non-white" colonies. One experiment to do with state-sponsored schooling was carried out in north India in the early 1850s. It was on a large scale and, almost uniquely, aimed to engage the poor village boy by building a system designed to wean him onto a sympathetic curriculum that contained both Western and Eastern elements.

This article is about that important experiment. Fifteen years before Forster's Education Act, a village elementary schooling system called Halkabandi (circle of villages) was tested in the North Western Provinces (NWP) and in the Punjab, both located in British north India. This was the first large-scale attempt by the British at state-run education for "the masses" on the subcontinent. The size of the Halkabandi experiment was also impressive. The Punjab and the NWP together approximated to almost double the land area of England and double its population as well.

William Arnold, as the first director of public instruction in the Punjab, was the man responsible for implementing Halkabandi in that province. William had been interested in German critiques on English education as early as the 1850s, well before his brother, Matthew Arnold, or even his brother-in-law, W.E. Forster. ${ }^{1}$ His main concern was to avoid the pitfalls of English schooling, as he saw it, especially the monopolization of schooling by the wealthy and the lack of a curriculum sympathetic to the needs of the labouring poor. His position of authority in the Punjab gave him a real chance to show this was possible even though his efforts were ultimately to end in failure.

The initial push for the Halkabandi village scheme owed its origins to longer-standing intellectual precursors to do with "orientalism" on the subcontinent. These were quite different from anything experienced in Europe. As well, the merits of compulsion were not seriously contemplated in India until 1910. However, what is important is that this large-scale Halkabandi village experiment in north India was believed by its proponents, and especially Arnold, to be capable of producing something better than what was on offer in England or elsewhere in the empire. For Arnold, "the masses" in

1 While on leave from India in 1853 Arnold translated the following book: L. Wiese, German Letters on English Education (London: Longmans, 1854). The letters praised the efforts of Dr Kay-Shuttleworth, and urged the establishment of a secular scheme of national education and the introduction of compulsory education for the poorer classes. Upon William Arnold's early death off the coast of Gibraltar in 1859, his four orphaned children were to find a home in the household of W.E. Forster. 
India represented the same philanthropic project as did their counterparts in England. ${ }^{2}$

Models for the institutionalization of education had been implemented by the Dutch as early as 1808 , by Horace Mann's State Board of Education in Massachusetts in 1837, and even by the Prussians. In Canada, unlike most other "white colonies," educational evolution (from the abandonment of the General Board of Education in the 1820s to the School Act of 1841 and, finally, the more durable educational settlement of 1850), had much to do with finding a bureaucratic coalescence between the central authority, the county boards, and other competing stakeholders. ${ }^{3}$ However, Arnold, in India, believed his systemic government-run model offered even greater immediacy and opportunities for "improvement" for the village boy who faced the barriers of both class and race. He would also try to bring about such social mobility by selectively engaging the ancient learning heritage of the East.

\section{The Raj Educational Context}

The subcontinent was a unique place for schooling in the Empire. In Africa in the nineteenth century, as the government "flag" was planted on the "dark continent," outright annexation meant the sudden imposition of foreign institutions and traditions. However, in India the scenario was different. As Lynn Zastoupil and Martin Moir contend, East India Company power was built within the confines of a well-established pre-existing political and social order where the shrewd manipulation of social customs and cultural symbols helped deliver a bountiful trade. ${ }^{4}$ Also, in the 1820 s and the 1830 s, British "orientalism" had built upon the earlier Enlightenment fascination with the culture and the learning traditions of the East. The subtle ideas of men like Ram Mohan Roy reinforced the confluence of West and East. As well, in Chrestomathia, Jeremy Bentham's "Psammographic principle" advocated student writing in sand rather than on slate, and the "Madras system" of pupil monitors. ${ }^{5}$

2 W.D. Arnold, "Memorandum as to a Central College at Lahore,” Jan. 12, 1856, no. 236, Oriental and India Office Collection (OIOC), P/201/53.

3 Bruce Curtis, Building the Educational State: Canada West, 1836-1871 (Philadelphia, PA : Falmer Press, 1988), 15, 22-23, 70, 131-32.

$4 \quad$ Lynn Zastoupil and Martin Moir, The Great Education Debate (Surrey: Curzon, 1999), 1.

5 Jeremy Bentham, “Chrestomathia,” in William Burston and Martin Smith, eds., The Collected Works of Jeremy Bentham (Oxford: Clarendon Press, 1983), vol. 8. 
From the earliest days of the raj, experiments by Europeans in education were mostly school-based and involved the written word rather than traditional oral pedagogy. British education governance became more institutionalized and self-conscious after T.B. Macaulay's Minute of 1835 and Charles Wood's important Education Despatch of 1854, the latter purposely advocating active measures to extend education to "the masses," well ahead of movements in the same direction at the metropolis. Thomas Metcalf even suggests, in a recent book, that India was the "laboratory for the creation of a liberal administrative state and from there its elements - whether a state sponsored education, the codification of law, or a competitively chosen bureaucracy - could make their way back to England itself."

I would contend that such a hypothesis can be taken too far. Clearly there were other forces at work in England. But the early experience of the British administrator, and his struggle to maintain his rule over a sprawling subcontinent, did make it seem to some contemporaries that he was creating a model of bureaucratic excellence that ought to be followed "at home." As such, attempts on the subcontinent to institutionalize and systematize their own form of provincially based state education appeared to offer some kind of lesson, even though the assembly of a tame clientele was the real aim of all but the most exceptional educational administrator on the subcontinent, especially after the Mutiny of 1857.

\section{The “Orientalist" Origins of Government-run Village Education in North India}

The early intellectual precursors to state-run education on the subcontinent were, in fact, quite different from anything found in Europe. They stemmed from the work of early so-called "orientalists" who believed in teaching in the local languages of India and who were mostly Europeans receptive to the knowledge of the East as an important part of any government-devised curriculum. The most

6 Macaulay's Minute of 1835 prescribed that government education to be conducted in English rather than the vernaculars or the classical languages of Sanskrit, Persian or Arabic. Sir Charles Wood's Education Dispatch of 1854 was considered the most significant India Office directive of the nineteenth century. It supported the learning of English at the upper levels of the schooling hierarchy and it supported missionary education. However, most significantly, it urged the spread of education beyond elite groupings who were taught in English or the classical languages. As a result it focused on the idea of mass education in the vernaculars, rather than relying on the out-dated notion of downward "filtration."

7 Thomas Metcalf, Ideologies of the Raj (New Delhi: CUP, 1998), 29. 
recent work concerning some of them can be found in Jyotsna Singh's Colonial Narratives. ${ }^{8}$ Whilst Wood's Education Despatch of 1854 was the principal India Office education directive during my period of study, it was the orientalist education writings of the 1820 s and the 1830 s, as well as the important anglicist/orientalist controversy of 1835, that remained the intellectual reference for Indian educational thinkers by the middle of the century.

Early orientalist thought was born out of the political need to conciliate. As part of Warren Hasting's strategy to keep the "literate classes" loyal, section 43 of the 1813 India Charter Act deferred to "ancient" learning via traditional methods, and it declared a respect for Sanscritic ethics. ' The approach did not assume the primacy of European knowledge. For example, early orientalists such as H.H. Wilson and H.T. Prinsep were advocates of Eastern algebra, geometry, and literature, although they also railed against any coalescence of Newtonian Science with that of the Eastern mystics or of the cosmos. ${ }^{10}$

Unfortunately such "orientalist" sympathies for the learning of the East did not continue to hold sway with the British government. In the famous Minute of 1835, which focused on the relatively few city-based schools the British had already established or had appropriated, T.B. Macaulay and the so-called anglicists were to win London's approval for government education to be carried out in English and not in the primary Indian languages. ${ }^{11}$ The decision was a perceived defeat for the orientalists who had advocated instruction mainly in Urdu, Hindi, or Persian in these schools.

However, such a reversal did have an unexpected side-effect. Macaulay's "victory" was to spur key orientalists to pursue their ideal

8 Jyotsna Singh, Colonial Narratives: Cultural Dialogues (New York: Routledge, 1996), chap. 2.

9 “Court of Directors' Public Department Despatch to the Governor-General in Council of Fort William in Bengal, dated 3 June, 1814,” Bengal Draft Dispatches, OIOC F/3/31, pp. 25-43, in The Great Indian Education Debate, ed. Lynn Zastoupil and Martin Moir (Surrey: Curzon Press, 1999), 93-97.

10 Wilson and Prinsep were members of the General Committee for Public Instruction (founded in 1823), which also had been concerned with the practical consideration of allowing existing institutions, like the Calcutta Sanscrit College and the Calcutta Madrassa, to follow their oriental curriculums. Zastoupil and Moir, The Great Indian Education Debate, 147. Their defence of Eastern algebra, geometry, and literature was uncompromising. They also asserted that the premature introduction of compulsory English would result in a "rudimentary engraftment" of Western knowledge. "Letter from J. C. C. Sutherland, secretary to the General Committee of Public Instruction, to H.T. Prinsep, secretary to the government of India...dated 22 January 1835,” OIOC P/186/66, ff. 258-66.

11 Gauri Viswanathan, Masks of Conquest (London: Faber and Faber, 1989), chap. 2. 
of education taught in the languages of the subcontinent at the "lower" village level instead. William Adam was the most significant of these men. By 1838 he had already spent three years surveying village schools in Bengal and Bihar in the northeast of India. ${ }^{12}$ His thorough methodologies, and his funding by government, helped give greater prominence to new ideas about how village instruction might be carried out by government. ${ }^{13}$ The call was powerful because it was predicated upon his illustration of the vibrancy and variety of the thousands of indigenous schools that existed. His views were also legitimized by small village schooling experiments already attempted by others. Mountstuart Elphinstone (Governor of Bombay, 1819-27) and Thomas Munro (Governor of Madras, 1820-26) were responsible for some of these. In the 1830s, Lancelot Wilkinson, as assistant resident at Bhopal, engaged the local pandits (Hindu teachers) to combine traditional Eastern learning with that of the West. As well, Henry Hardinge, as governor-general, was to sanction the establishment of almost 100 schools in Bengal in 1844, with a curriculum of "vernacular reading, writing, arithmetic, geography, and history of India and Bengal."14

This then was the background to the development of Halkabandi in India's northwest. As part of this "orientalist"-inspired tradition, village school experimentation began in the Punjab and in the NWP in the early 1850s. ${ }^{15}$ The reforming James Thomason (Lieutenant Governor, NWP) shared Wilkinson's view that government-led vernacular education was needed as a priority for the newly formed NWP. In spite of Macaulay's minute, whose directives had been implemented a decade earlier, minor English schools were abolished and instruction in English was confined to the colleges. In 1852, the ambitious village school scheme called Halkabandi was founded. A year later, in the Punjab, planning for the implementation of a similar

12 Anathnath Basu, Reports on the State of Education in Bengal 1835 and 1838 (Calcutta: Calcutta University Press, 1944), xix-xxiii.

13 Adam's report was ignored when it was published three years after the anglicist/orientalist debates of 1835. The General Committee of Public Instruction (GCPI) claimed it had encouraged learning in the local languages by extending the use of them in government offices and colleges: Sec. to the GCPI to Sec. to the Government of India, Aug. 31, 1838, OIOC F/4/1846, no. 77636, 61-83; for the Board's unfavourable response to Adam's third report see J. Sutherland to H. Prinsep, Dec. 4, 1838, OIOC P/186/86, no. 19, cited in Zastoupil and Moir, The Great Education Debate, 57n129.

14 Kazi Shahidullah, Pathshalas into Schools (Calcutta: OUP, 1987), 15, 25, 29, 33.

15 Rev. J. Long, "Brief View of the Past and Present State of Vernacular Education in Bengal," in [W.] Adam's Report on Vernacular Education in Bengal and Behar Submitted to Government in 1835, 1836 and 1838, ed. Rev. J. Long (Calcutta: Home Secretariat Press, 1868), 13-18. 
scheme was begun. It was to become the most sympathetic government scheme the British had to offer "the masses."

\section{The Principles of Halkabandi and its Institutionalization by Government}

By the standards of the time Halkabandi was revolutionary. It was designed to integrate teaching across several levels of schooling and in so doing attempt to broach an important cultural and class divide. This was the principal determinant for the bureaucratic structure that was to be built to support the scheme. Once established, Halkabandi's supporters hoped to use it as a device whereby poor boys, who could speak only the local language, would be eventually drawn into a Western-based curriculum.

The scheme had as its focus the establishment of hundreds of new village schools and the appropriation of some indigenous schools, which would then be hitched to more substantial "tahsili" government schools in each tahsil (the lowest government administrative level in the province). "Halqua," meaning circle, referred to clusters of villages which supported one governmentsponsored village school teaching in the local languages. Each village schoolteacher was to receive a modest stipend of between Rs 5 and Rs 10 per month paid by the government; a small allowance was made for school building maintenance and they were to be subject to inspection.

Superimposed above the more numerous village schools, the tahsili schools (teaching a more European-oriented curriculum) formed the second schooling tier of the scheme. They numbered about 100 in each province, with two "native" teaching positions each: one senior, one junior, entirely funded by the government at salaries ranging from Rs 15 to Rs 25 and Rs 6 to Rs 12 per month respectively. The salaries were deliberately calculated to compare favourably with those paid to teachers of non-participating indigenous schools, who commanded, on average, Rs 8 per month, if they were not already paid in maunds of grain or in a small land grant in lieu. ${ }^{16}$ The designation of senior and junior teacher also made promotion in

16 Sec. to the Board of Administration to Sec. to the Government of India, Nov. 20, 1850, no. 113, “Series B,” National Archives of India, New Delhi. 
the tahsili school an incentive for compliant teachers. ${ }^{17}$ As well, provision was made for two scholarships of Rs 24 per annum for each tahsili school to offer its most able scholars from a general-purpose fund of Rs 192 allocated to each school. These scholarships were designed to connect the tahsili schools with the next level of school: the zillah (district) schools.

The idea was that while participation in village schooling would be uncertain, the attraction of instruction in the local languages by the local munshi (language teacher) or pandit would induce poor boys to participate (when their parents could spare them from working in the field or in the local bazaar). After two or three years of mastering basic literacy and numeracy skills in their own language, they would then be induced to take the next step, which was in the local tahsili school. Here a government-sponsored curriculum would be taught that was much more closely controlled by the education department in each province. "Engraftment" of Western knowledge by this device was the aim of the innovation. The scheme was also seen as a necessary concession on the part of detached and experience-weary senior officials who had already found the language mosaic difficult to fathom and especially complex in the British-constructed provinces of the Punjab and the NWP.

The number of teachers embraced by the Halkabandi scheme reached more than 2,000 in each province by 1860; the total cost of Halkabandi to the government was substantial by the standards of the time. In the Punjab alone it consumed most of the education budget of some Rs 160,308, with a projected allocation of Rs 300,000 $(£ 27,907)$ from imperial revenues for the new department. ${ }^{18}$

17 The average age of government-appointed teachers varied considerably. In Kangra it was as high as 51.6, compared to just 22.4 in Amritsar. "Abstract Table B," included in "Education [Report]," July 31, 1858, no. 131-58, Punjab Secretariat Archives, Anarkali's Tomb, Lahore, Pakistan.

18 This was out of a total expenditure at the imperial level for education in India of Rs $21,60,000(£ 200,930)$ for the year 1856/7. Atmanand Misra, The Financing of Indian Education (London: Asia Publishing House, 1967), 184. The conversion figure I have used is at the rate of $£ 1=$ Rs10.12 annas, which was the rate listed in the Money-Market section of The Times, Jan. 5, 1850, p. 5. I am grateful to Dr. Clive Whitehead of the University of Western Australia for this information. 


\section{William Arnold and the Implementation of Halkabandi in the Punjab}

For clarity, I will focus on the Punjab, where, between 1855 and 1859, the dynamics of the Halkabandi scheme are the most interesting. In the Punjab, Halkabandi's most ardent supporter was its director of public instruction, William Arnold.

Arnold's intellect attracted the province's Chief Commissioner, John Lawrence, who unashamedly described him as a man "of excellent talents, with a real turn for education." 19 His academic approach seemed most likely to bring off the delicate aims of Halkabandi, especially to do with weaning illiterate boys onto a Western-based curriculum. It was still too early to envisage exactly what this curriculum would be and just how the Halkabandi village school would respond to the European-tempered tahsili schools. But Arnold had faith that an agreeable educational nexus between East and West would be reached eventually, whereby due deference could be paid to the cultural and linguistic nuances of the East. This became his principal long-term aim. ${ }^{20}$

Arnold thought independently of his superiors in matters to do with the governance of India, especially regarding education. His attitude towards India was paternal, although his view was also critical of the commercial exploitation of the subcontinent by the British. ${ }^{21}$ This he saw as part of the spiritual impoverishment of the British in India, who lacked a sense of a higher civilizing mission in which education, amongst other things, could play a greater part. Arnold's interest in educational reform, like that of his brothers Matthew and Thomas Arnold Junior, was also encouraged by a youthful and ingenuous belief that substantive innovation was possible.

In 1855, in his new capacity as director of public instruction, he now hoped to do much more in the Punjab than even his contemporaries had attempted so far in England. He accepted that

19 Sec. to the Chief Commissioner to Sec. to the Government of India, May 1, 1854, no. 363, OIOC P/188/8. Lawrence in these early years also was genuinely deferential to Arnold's academic background. The Chief Commissioner's faith in Arnold's literary talents also prompted him to ask Arnold to write an official biography of his brother Henry Lawrence when the latter died in the North West Provinces during the Mutiny in 1857. Lawrence to Arnold, July 2, 1856 and Sept. 14, 1857, J. Lawrence Coll., MSS Eur.F.90, vol. 9, f. 1 and vol. 11, f. 277.

20 W.D. Arnold, “Memorandum as to a Central College at Lahore,” Jan. 12, 1856, no. 236, OIOC P/201/53.

21 See, for example, his autobiographical novel Oakfield (Surrey: Unwin Brothers, 1974), 223 [reprint with an introduction by Kenneth Allott]. This book was published in 1853, just two years before he became director of public instruction in the Punjab. 
elites in India, as in England, would always be able to buy a "superior" education. But he also saw the model of English education in the 1850s as something to be resisted because, as he saw it, it was still for only the wealthy few where vested interests actively precluded the poor from progressing to a college education. ${ }^{22}$ To his mind, emphasis, in the first instance, on Halkabandi at the village level was a way to prevent the same thing happening in the Punjab (as it had already done in the older provinces of India including Bengal). $\mathrm{He}$ wanted the education of the poor to be the first step in building a schooling hierarchy that would one day lead to the building of a university. For this reason he delayed establishing any government colleges in the province until "lower" government schooling was entrenched. As a result it was to be another ten years before the first government college was established in the Punjab.

For Arnold, active surveillance of Halkabandi was pivotal. Two European inspectors were assigned to his department to help with the supervision of its schools. But the number and dispersal of his new schools necessitated considerable delegation to indigenous stakeholders. Arnold had first-hand experience as a deputy commissioner at Amritsar, and it seems this was enough to forewarn him of the likely hostility he would face if government district officers were given responsibility for inspecting his Halkabandi village schools. ${ }^{23}$ Instead, he chose to circumvent this arm of civil government entirely and to employ his own "native" deputy inspectors, whom he called his "native supervisory agency." There were ten senior posts with a remuneration of Rs 200 per month and a travelling allowance of Rs 100 per month. A further 60 sub-deputy inspectors were appointed and paid up to Rs 80 per month with a travelling allowance of Rs 40. The so-called "native supervisory agency" was relatively expensive compared to the NWP scheme. However, this was largely because Arnold placed great importance on obtaining the services of the most able indigenous educators for these key posts, especially given that government prevented him using the indigenous schools as part of Halkabandi (which I will discuss in the next section). As a result, the total cost of the supervision was Rs 8,500 per month, almost double the entire cost to government of all the newly established tahsili schools. ${ }^{24}$

\footnotetext{
22 Arnold, "Memorandum as to a Central College at Lahore.

23 Arnold, Oakfield, Allott's introduction, 13.

24 "Appendix no.1, Proposed Schedule of Education Established for the Punjab," included in D.F. McLeod to Sec. to the Chief Commissioner of the Punjab, April 4, 1856, OIOC P/201/53, no. 236; D. McLeod to J. Lawrence, April 11, 1856, no. 237, OIOC $\mathrm{P} / 201 / 53$.
} 
Despite his intentions, Arnold, like his contemporaries, knew little of the many layers of indigenous culture and religion that would have to be considered if government education in the Punjab was to engage "the masses." His work over the next three years was to bog down with the onerous task of setting up a suitable distribution of participating village schools which then could cluster around the closest tahsili school, many of which he also had to establish. The initial planning took Arnold three months, and his work reflected some sympathy with the way former schools had been organized under Ranjit Singh (the former pre-British ruler of the region). The tahsili schools especially were to be established in strategic positions and Arnold began an extended period of work consulting with authorities in each district, as well as with the local zamindars (landowners). ${ }^{25}$

However, an important stumbling block still existed. Unlike the government of the NWP, the Punjab Secretariat (made up mostly of senior military men) refused to accept the validity of the pre-existing Punjabi indigenous schools of the province even though many of their teachers were to be appropriated into the new Halkabandi system. This was an important shortcoming. Earlier European estimates of indigenous literacy rates (that had resulted from the teaching of these schools) were put as high as 6 per cent. ${ }^{26}$ As well, European reports of the Persian schools and their ten-year curriculums also had been highly favourable. However, the practice of rote learning of religious texts, and the tradition of teachers begging to supplement their incomes, were later used by the Punjab government to discredit these schools.

Unofficially, Arnold attempted his own collation of indigenous village school statistics, perhaps hoping that his superiors would change their minds. His research in 1857 showed 6,248 schools for the Punjab, with an average school age that increased markedly as he moved from west to east across the province (for example, Peshawar: 5 years of age; Ambala: 12.4 years of age). Muslims made up 80 per cent of the teachers compared to just 20 per cent Hindu (no other groups were listed). Most schools taught in Persian, with only ten schools receiving any instruction in Persian Urdu. Punjabi was taught in 196 of these schools and only 112 taught in Hindi as far as he could

25 D F. McLeod to Sec. to the Chief Commissioner, April 11, 1856, no. 237, OIOC $\mathrm{P} / 201 / 53$

26 R. Montgomery to the Sec. to the Board of Administration, Nov. 8, 1850, no. 567, "B Series," National Archives of India. 
tell. ${ }^{27}$ But despite their number and their cultural significance Arnold was never given permission to use them in the new Halkabandi scheme.

Fortunately, in the short term there seemed enough social cohesion to mask this important omission. For example, Arnold's work was made easier because village constellations in the Punjab were already noted to be usually grouped in circular formations and this seemed conducive to the new scheme. Later administration reports also characterized these villages as having "one large cousinhood, having their own headmen, accustomed to joint action and mutual support.",28

\section{Arnold's Funding of Halkabandi, 1856-57}

Pivotal to the success of Halkabandi was the provision of stable funding. As with all significant endeavours in India by the British, a component of local contribution needed to be found. From the tahsil level upward, imperial money was allocated by Calcutta as the main source for establishing schools. But Arnold's village schools were to be almost entirely reliant on a 1 per cent education cess (tax). The cess was to be levied as part of the jumma-bundee (rent roll tax) on land holdings. ${ }^{29}$ As such it was a hidden, but broadly levied, imposition. It would fall most heavily on the agricultural classes, but it seemed equitable since the village schools were chiefly for their benefit. The money it could raise was promising given that a similar cess in the NWP had already raised an impressive Rs $600,000 .^{30}$

The education cess was never championed by the government as a discrete tax for education of "the masses." Rather, its significance lay in the willingness of the India Office in London to allow a small part of its general land revenue to be siphoned off for educational purposes. Although itemized separately, the tax was seen as part of the general land revenue which the British, as successors of the Sikhs, claimed as their right to continue to collect. The utility of its hidden

27 “Table C," “Abstract Statement of Indigenous Village Schools Existing in the Punjab in the Year 1857-8," included in “Education [Report]," July 31, 1858, no. 131-58, Punjab Secretariat Archives, Anarkali's Tomb.

28 "General Report on the Administration of the Several Presidencies and Provinces of British India during the Year 1855/6" (1857), pt. ii, p.15, OIOC V/10/2.

29 For a detailed account of how the land tax was assessed in the Punjab in the 1850s, see R. Saumarez Smith, Rule By Records (Delhi: Oxford University Press, 1996), 71-74. 30 H.S. Reid, "Report on Indigenous Education and Vernacular Schools in Agra, Bareilly, Etawah, Farruckabad, Mynpoory, Muttra, Shahjahanpur for 1852-3” (1853), pp. 36-37, OIOC, V/24/927. 
nature was also to be best illustrated when the "decentralization" scheme of 1871 later encumbered municipal and district boards with responsibility for establishing separate funds for educational purposes. After this time non-agricultural Punjabis were to show themselves to be very reluctant to contribute money expressly for the purpose of government education via the local board. Yet the struggling agricultural classes were to continue to do so in substantial sums until the 1880 s, by way of the hidden 1 per cent cess.

Given that this was the funding base for Halkabandi, Arnold, for reasons of equity, insisted that his tahsili and village schools must be spread evenly throughout all tahsils. But such broad dispersal also meant that only twenty-five villages in any one tahsil could be given a Halkabandi village school. The criterion also made the placement of these schools especially exacting. Eventually no village, Arnold calculated, should be more than two miles from the nearest Halkabandi school and its placement should be guided by "considerations of geographical situation, of the state of existing indigenous schools, of the relation of the village chosen to other neighbouring villages and then establishing a school which may subserve the wants not of one village only, but a cluster of villages." 31 This was highly ambitious given the lack of British knowledge of the existing indigenous education endeavour, especially in the more tribally based western regions of the Punjab. However, Arnold pressed ahead and requested that the cess be levied uniformly across the province after the 1856 harvest and that he, and not the Punjab Secretariat, be charged with the distribution of these funds. ${ }^{32}$

As well, Arnold saw no difference, at least as far as funding was concerned, in the potential for education to reach "the masses" in India compared to the working classes in Great Britain. In fact, both he and his NWP counterpart saw their funding measures as a model for what should happen in England. The director of public instruction in the NWP calculated that the 1 per cent cess subsidy meant village education cost government about Rs 4 per student each month in his province and this approximated, he reckoned, to a local rate of six pence in the pound in England. This was the level of government

31 W.D. Arnold, “The Beginnings of Western Education in the Punjab. Mr Arnold's Report on Public Instruction for the Year 1856-7," in Selections from the Educational Records, ed. James Richey (Calcutta: Government Printing, 1920), vol. ii, 295-96.

32 Director to Financial Commissioner, April 30, 1856, no. 105; Financial Commissioner to all Commissioners, May 5, 1856, nos. 106-7, "Press Lists of Old Records in the Punjab Civil Secretariat," second edition, vol. xxv, OIOC V/27/37/25; John Lawrence to William Arnold, Dec. 12, 1856, J. Lawrence Coll., OIOC MSS Eur. 90, vol. 10, f. 76. 
student subsidy that reformers were lobbying for to support elementary education in England. Arnold's brothers, Matthew and Edward, were to take up this cause later in the decade in Great Britain. $^{33}$

\section{Arnold's Foundation of the New Tahsili and Village Schools, 1857-58}

By early 1857 Arnold was in a position to begin supervising his newly operational department. His work continued unabated even after the initial shock of the Mutiny later in the year. The financial restrictions this event would bring were not yet apparent and he worked assiduously to extend government village schooling throughout the province without further testing. The politically neutral 1 per cent cess funding turned out to be Halkabandi's greatest strength despite worries about its long-term collection. As a consequence, the Halkabandi system of tahsili and village schools was able to grow rapidly in 1857 and 1858 in the central and eastern Punjab. The director pressed on relentlessly to establish as many schools in each district as cess funding would permit. In 1857 government tahsili schools were established first in a clockwise direction near Lahore (in the centre of the Punjab). The director's strategy was not to linger in any one district, but to establish these schools in quick succession in as many districts as possible by the end of 1858. In this transient stage, no curriculum control was yet possible and schools higher up the institutional tree, into which the tahsili schools were to feed, were still in their infancy.

Arnold found the work laborious and, after the hot summer of 1858 (without the usual respite of the summer months in the hill station of Simla), he was driven to complain to McLeod,

I need not remind you that I have to traverse great distances, I have to visit Mooltan, and Derajat, Rawalpindi and Peshwur, Delhi and Hissar, Amballah and Simla and it is necessary therefore for me to travel with great rapidity. I have to keep up a camp, but at the same time to be constantly leaving it, and travelling by express carts or Palanquur, Horse or Camel Dak. ${ }^{34}$

33 John Hurt, Elementary Schooling and the Working Classes (London: Routledge and Kegan Paul, 1979), 10-15.

34 Director to Financial Commissioner, Nov. 19, 1858, no. 548, OIOC P/203/12. 
Traversing the flat and dusty plains of the Punjab by this means of transport justified the objection. But by the end of his term in office his excursions had produced 142 tahsili schools throughout the province. $^{35}$

The establishment of the much more numerous Halkabandi village schools designed to link into the tahsili schools was to prove much more problematic. The order in which they were established suggests that it would have been beyond the capacity of Arnold to oversee the establishment of them all. His education report for $1857 / 58$ detailed 633 new village schools established in the autumn of 1857 in the east of the province. Surplus cess funds also allowed for the construction of new village school buildings. ${ }^{36}$ But progress was uneven, with the establishment of Halkabandi tahsili and village schools in the remote western districts of Dera Ghazi Khan and Peshawar delayed until 1859. ${ }^{37}$

But Arnold's efforts were eventually to bear fruit. His success in establishing his new village schools was documented comprehensively for the first time in early 1860, after the government of India required all provincial education reports to include statistical returns in prescribed tabular form. The figures were impressive. At their peak in 1858/59 there were 2,029 such institutions. ${ }^{38}$ The average daily attendance at each of these schools was put at eighteen. ${ }^{39}$ By 1860 there were 45,686 Halkabandi village school scholars in the province. The village schools also exhibited the expected diversification in teaching content based on local language and custom, at least as far as the central and eastern districts were concerned, which were the regions known best to the British.

Arnold's unshakeable commitment to Halkabandi, and the educational success he hoped it would eventually yield, also seemed to excuse in his mind any short-term chaos. He claimed all the

35 A.R. Fuller, "Report on Popular Education in the Provinces under the Punjab Government for the Year 1859-60," p. 6, OIOC L/PJ/3/1157.

36 Director to Financial Commissioner, Nov. 30, 1858, no. 173, "Press Lists of Old Records in the Punjab Civil Secretariat" second edition.

37 A.R. Fuller "Report on Popular Education in the Punjab,1861/2," OIOC V/24/928, App. no. 3 A.

38 A.R. Fuller "Report on Popular Education in the Provinces under the Punjab, Year 1859/60,” OIOC L/P\&J/3/1157, p. 6.

39 "Report of the Provincial Committee for the Punjab of the [Hunter] Education Commission” (1884), SOAS Library, University of London, p. 8. Arnold's successors claimed a much lower figure of 27,264 scholars, which is probably less accurate given their efforts to play down the uility of Halkabandi. A.R. Fuller, "Report on Popular Education in the...Punjab for the Year 1859/60,” p. 6, OIOC L/P\&J/3/1157. Arnold also established additional village schools in both Delhi and Hissar upon their acquisition by his department. 
schools to do with the scheme were set up with the help of his team of deputy and sub-deputy inspectors. The pace of his work suggests the organization of these schools must have been incomplete and probably many existing indigenous village schools were enlisted into his scheme without the consent of the government, as had happened in the NWP. ${ }^{40}$ However, the tahsili school, around which these village schools were placed, provided some reference. Teachers were also recruited from nearby indigenous schools and while there was no curriculum to obey Arnold's speed was possible.

Yet the prospects for the future were highly speculative, even with the native supervisory agency in place, and Arnold openly admitted that more sub-deputy inspectors were needed so that "the supervision of village schools will be far more effectual than it is or possibly can be at present." ${ }^{41}$ More significantly, what he failed to consider was the response of the district officers, who were already frightened by the chaos wrought by the Mutiny of 1857 in the neighbouring NWP. At this delicate stage of Halkabandi's development, it was to be their resistance that ultimately brought a change in direction for the entire schooling enterprise by the government of the Punjab.

\section{The Obstacle of the District Officer and the Ending of Halkabandi in the Punjab}

As mentioned, Arnold had been an assistant commissioner in the district of Amritsar before becoming director of education, but this background did not help mollify his former Indian Civil Service (ICS) colleagues. ${ }^{42}$ Their onerous duties concerned most aspects of British governance including law enforcement, sanitation, communication, and the regulation of commerce. Their co-operation was also essential for Arnold's village schoolwork to succeed. The officers were needed chiefly for the supervision of the erection of the new school buildings once the modest supply of suitable existing dwellings began to dry up.

40 None of the educational reports for the North West Provinces or for the Punjab document this happening. However, this claim was made thirty years later in relation to the North West Provinces. F.W. Thomas, The History and Prospects of British Education in India (Cambridge: George Bell \& Sons, 1891), 44.

41 "Extracts from Mr Arnold's Report on Public Instruction in the Punjab 1857/8," dated June 25, 1858, paras. 3-9, 11, 14, in Selections From the Educational Records, pt. ii, 300-306. These were taken from the original manuscript lodged in the India Office, which, it appears, like Arnold's report for the previous year, is no longer extant. 42 Meriol Trevor, The Arnolds (London: The Bodley Head, 1973), 95. 
The regular payment of Halkabandi village teachers was also the responsibility of the deputy commissioners, as was the transferral of the education cess proceeds to Arnold's department. ${ }^{43}$ However, by late 1858, there were chronic delays by the district officers in carrying out these last two tasks. ${ }^{44}$ Their obdurance was largely because they viewed the new experiment in village schooling as an unnecessary encumbrance upon the more pressing duties of an ICS officer in the post-Mutiny Punjab. The problem was to endure despite the chief commissioner's attempts to issue specific instructions to all deputy commissioners, as well as to the inspectors of schools, to compel them to work together more effectively. ${ }^{45}$

The hostility of the district officers stemmed mainly from their ethic of bureaucratic control and accountability, which they saw as running counter to the director's unfathomable educational philosophy of inclusion imposed at the cost of substantial short-term financial wastage. To them, Arnold's mechanism for academic control was only through the aegis of his "motley" team of sub-deputy inspectors. What most district officers preferred instead was the more easily controlled and centralized large district and Anglo-vernacular schools which most other provinces in India had built as the centrepiece of their respective education departments.

However, Arnold's most cherished goal was to continue to resist building such institutions too early, given his ongoing fear that education might regress to serve merely the wealthy elites of the province. Even after the Mutiny his priority remained doubling the number of indigenous sub-deputy inspectors in each district to ensure, as much as possible, the orderly organic growth of his scheme. He also wished to continue to give greater incentive for indigenous teachers to apply for positions in the tahsili schools (sometimes

43 Financial Commissioner to all Commissioners, April 17, 1855, no. 85, "Press Lists of Old Records in the Punjab Civil Secretariat," second edition.

44 Director to Financial Commissioner, Oct. 19, 1858. nos. 145-1304, "Press Lists of Old Records in the Punjab Civil Secretariat," second edition; Deputy Commissioners of Ambala, Thanesar, Ludhiana, Ferozpore, Simla, Jullundur, Hoshiarpur, Kangra, Lahore, Amritsar, Sialkot, Gurdaspur, Gujranwala, Jhelum, Rawalpindi, Gujrat, Sharpur, Multan, Jhang, Gugera, Leiah, Kangra, Dera Ismail Khan, Dera Ghazi Khan, Peshawar, Huzara, Kohat, to the Financial Commissioner. April 1858, no. 241; Director to Financial Commissioner, May 31, 1858, nos. 58-613. The districts of Huzara and Leiah were the only districts that remained unco-operative. Commissioner trans-Sutlej States, Aug. 8, 1855, nos. 88-89, "Press Lists of Old Records in the Punjab Civil Secretariat" second edition.

45 Sec. to the Government of the Punjab to Sec. to the Financial Commissioner, Jan. 24, 1859, no. 215; Financial Commissioner to all Commissioners, Judicial Commissioner, Accountant General, Civil Auditor and Director of Public Instruction, Feb. 11, 1859, nos. 48/487-494, "Press Lists of Old Records in the Punjab Civil Secretariat," second edition. 
staffed by Europeans) by increasing their stipends upon promotion to a hefty Rs 50 per month, after beginning at a rate of Rs 15 per month. The prerequisite for promotion was training in the closest government-controlled normal school, with its Western-based curriculum. This, Arnold asserted, would also make them more accountable to the deputy inspectors as the village school system grew and "our demands become more exacting" on these teachers. ${ }^{46}$

Such niceties, however, were to alienate further the impatient district officers. Their powerful lobbying to divert imperial funds so to accelerate the building of more permanent and "efficient" zillah schools and a college at Lahore was something the director chose to ignore. When the financial ramifications of the Mutiny became known (which caused an unanticipated restriction of imperial funding for his department from Rs 300,000 to 200,000), Arnold could no longer promise that the next step in the schooling hierarchy, the district schools, could be built expeditiously if Halkabandi was also to continue. The problem left Arnold with a bottom-heavy system of tahsili and village schools, which was perilously difficult to control and focus.

Arnold's enthusiasm for the rapid establishment of Halkabandi now seemed to have delivered an over-extended and poorly supervised village school system. This gave the district officers and other opponents the ammunition they needed to overturn Halkabandi in favour of something that resembled far less the proposals of Wood's education dispatch of 1854 to extend education to the "masses." The structural problems created by the funding restrictions suddenly imposed by Calcutta upon all provinces after the Mutiny meant Arnold's scheme was curtailed just at a time when it needed ongoing increases to see it through its transitional stage. The push by the district officers to rid themselves of the tiresome "native supervisory agency" and their wish to divert funds to the more rapid development of centrally located larger schools soon became overwhelming.

With little prospect of saving Halkabandi, and with personal tragedy of his own to deal with, Arnold chose to resign in January $1859 .^{47}$ Lawrence was also to resign as chief commissioner just one month after Arnold. His replacement, Robert Montgomery, quickly shed any commitment he had earlier shown to Halkabandi and began

46 W. Arnold to D. McLeod, Dec. 27, 1856, no. 193. Approval given to this, "Extract from the Proceedings of the Rt. Hon. the Governor-General of India in Council," March 6, 1857, no. 1037, OIOC P/202/17.

47 Arnold’s wife died in March 1858. 
rapidly to "centralize" education in the province around government and mission schools in the cities even though the agricultural education cess remained in place. This robbed the Punjab of a scheme most likely to win the British the prize of engaging, at least in part, large sections of the population on the issue of education. Arnold never got the chance to experiment further by employing the next highly ambitious step in his vision - the development of a curriculum sympathetic to Eastern learning which could also integrate the lowest tiers of government education so that some poor boys would be able to progress eventually to a college education.

\section{Centralized State Schooling in North India: The End of Arnold's Vision}

The decline of Halkabandi ended the best chance the British had to enlist the poor in India into their own education system. The hiatus in the academic ladder between the village school, the Anglo-vernacular school, and then the college was to become insurmountable to most poor boys in the next two decades, despite Arnold's earlier hopes. This was mostly because the complex linguistic mosaic of north India precluded broad participation at schooling levels above the village, especially when the imposition of a Western-based curriculum was attempted using only Persian Urdu as the medium of instruction. ${ }^{48}$ There were also, of course, the broader cultural incompatibilities to do with the imposition of a Western-oriented education itself. This, the custodians of swadeshi (self-sufficiency, in opposition to British colonial governance), the Arya Samaj, the Servants of India, and the Indian National Congress, were only too happy to illustrate during the next three decades and beyond.

However, the remaining Halkabandi schools in the Punjab, and their counterparts in the NWP, now were used as a nominal institutional base for a schooling hierarchy that was quickly built in north India between 1860 and 1865 . Village schools were still used to justify the development of a unitary education system that could be copied elsewhere in India, even though their number was now halved. Money was now diverted for the development of district schools, district normal schools, Anglo-vernacular schools, and several

48 Persian Urdu, as the designated court language of British administration in the Punjab, was also deemed the medium of instruction in 1855 for larger schools. This was even though most poor village boys only spoke local language dialects. 
colleges. Just a decade later, Punjab University was approved by the India Office in London to sit astride the edifice. The education cess also became entrenched as the chief instrument of local funding. (This contrasted with England where the Lancashire Public School Association had proposed a local rate as early as 1847 but, even in the 1860s, the Commons continued to reject such an idea.) In 1870 the state system of education in north India looked complete to contemporaries in London, with its universal examination system, its multi-tiered level of schooling inspection, its middle school, and its early textbook committees, all of which theoretically served at its base the aspiring but illiterate village school boy. The only task left, it seemed, was to elevate participation rates.

There were also many people available to relay the message back to England. Retired ICS officers, including ex-provincial governors as well as former India Office Secretaries of State, such as Sir Charles Wood and especially Lord Stanley, were still active in London. As well, Sir John Lawrence was later to become chairman of the London School Board. They knew the extent of educational innovation in India and were willing conduits throughout the proximate halls of Westminster. It seemed the strong polity of raj governance had even delivered something ahead of educational developments at the metropolis.

As already mentioned, the precursors to Forster's Education Act of 1870 were to be very different from those found in British north India. But in the 1850s and 1860s, north India had been more conducive to the building of another kind of state-run education system. Unlike England and its divided Whig and Tory governments in the mid-nineteenth century, entrenched raj governance ensured far greater inter-relation and integration between education administration and the other areas of Indian government bureaucracy. This meant provisional governments could develop with facility unitary provincial education systems that looked deceptively impressive. Also, in India, a single curriculum in each large province could be developed rather than one fragmented by considerations of class as in England, especially after the Taunton Commission of 1868. There were also fewer possibilities in India for the Established Church to try to assert a monopoly over the education of the poor and to divert state funding to voluntary bodies instead.

Finally, it is important to note that the educational example of the raj, though momentarily impressive in the middle of the century, was also just as fleeting when the longer-term state educational development on the subcontinent is considered. This is why I am not convinced by Metcalf's contention that India was a laboratory for the 
liberal administrative state, at least as far as education was concerned. After 1875 fundamental changes saw the Indian system become the poorer cousin of its English counterpart. For example, government school inspectors and schoolteachers in India were not a force for change and did not contribute substantively to the elevation of the state teaching profession as did their fellow HMIs (Her Majesty's Inspectors) in England. As well, moves to embrace the state education system itself were a source of provincial pride for the industrial cities of England but, in India, the indigenous city boards and their education subcommittees remained apathetic throughout the nineteenth century.

Bruce Curtis's able work on Canada West has demonstrated that conflicting education administrators created another kind of bureaucratic dynamism, where the political sites of the central authority and the local authorities reacted against the defects of the other. ${ }^{49}$ However, in India, the pervading ICS ethic of control and "efficiency" meant this kind of plurality was never as robust even though most education officers on the subcontinent belonged to a separate department. The dynamic of state-supported experimentation in education in the mid-nineteenth century was largely lost to the subcontinent after 1875 , whereas the reverse was probably true in England. By the end of the century, schooling under the raj in north India became increasingly centralized and the preserve of elites. The influence that flowed much more strongly from England by that time was not to do with the merits of state schooling, but rather notions to do with "athleticism" and the ethos of the English public school, ${ }^{50}$ something that William Arnold, for one, would have greatly regretted.

49 Bruce Curtis, True Government by Choice Men? Inspection, Education and State Formation in Canada West (Toronto: University of Toronto Press, 1992), 193-98.

50 See James Mangan, The Games Ethic and Imperialism (New York: Viking, 1986). 